\title{
THE RURAL SECONDARY SCHOOL TEACHERS' USE OF I-THINK IN THEIR CLASSROOM
}

\author{
Nazrah Sarbini ${ }^{1}$ \\ The Faculty of Education, \\ Universiti Kebangsaan Malaysia (UKM), Malaysia \\ (Email: nazrahsarbini1975@gmail.com) \\ Melor Md. Yunus ${ }^{2}$ \\ The Faculty of Education, \\ Universiti Kebangsaan Malaysia (UKM), Malaysia \\ (Email: melor@ukm.edu.my)
}

Accepted date: $14-04-2019$

Published date: 17-07-2019

To cite this document: Nazrah, S. \& Md. Yunus, M. (2019). The Rural Secondary School Teachers' Use of I-Think in Their Classroom: The Reality. International Journal of Modern Education, 1(1), 86-96.

DOI: $10.35631 /$ ijmoe. 11008

\begin{abstract}
The Malaysian Ministry of Education has introduced the new Education Blueprint with the objective of elevating the Malaysian education standard to international level. The fourth industrial revolution prompts the urgent needs for transformation in the way teachers teach in class. The researcher believes that the use of I-THINK can be an effective approach to teach English in rural schools to promote students' ability to think critically. However, despite the efforts executed, the level of practice on the use of i-THINK among English language teachers in rural secondary schools after the training and exposure is average. This paper aimed to investigate the attitude and practice level of English language teachers in rural secondary schools on the use of $i$-Think maps. Data was collected via a questionnaire survey of ESL school teachers in Merlimau Zone, Melaka. The data were analyzed using descriptive statistics. The findings show that the teachers had positive attitudes towards I-THINK use in the classroom despite the average practice in their teaching. The implication of the study is the Ministry of Education through effective supervision of the District Education Office should ensure the teachers go for I-THINK courses to arm them with ample knowledge to successfully implement I-THINK maps in their practice.
\end{abstract}

Keywords: Creative And Critical Thinking Skills, I-Think In Classrooms, Rural Secondary Schools, The Malaysian Education Blueprint, Thinking Maps

\section{Introduction}

Thinking maps are a set of graphic organizer techniques used in primary and secondary education. There are eight diagram types that are intended to correspond with eight different fundamental thinking processes. They are supposed to provide a common visual language to information structure. 
Students are enabled to think with depth and apply their thinking to complete tasks. The tool provides a consistent and a compatible way for teachers to present information and for students to learn and retain it as i-Think combines the cognitive thought processes of learning with the visual representation of information found in graphic organizers.

Students will use critical thinking when participating actively in their own studies because thinking skill is one of the six attributes every $21^{\text {st }}$ century student should possess as highlighted by the Malaysian Education Transformation Plan (2013-2025). Higher cognitive skills which include the ability to analyse, synthesize, evaluate (Anderson \& Krathwohl, 2000) are triggered. In short, the i-Think programme improves not only students' but also teachers' thinking abilities.

The launching of i-Think programme was done by the Prime Minister of Malaysia on $13^{\text {th }}$ March 2012. In 2013 training students to use the thinking tools in 1000 schools commenced. Training of teachers in 8994 schools was also executed in the same year. In 2014 the training of students continued and the research on i-Think implementation was carried out.

However, despite the well-planned and vigorous efforts, the level of practice on the use of i-THINK map among English language teachers in rural schools after the training and exposure was low. Sidek, Mohamad \& Sabri (2013) illustrated that i-Think programme was still a new concept and there were still insufficient number of researches which assessed the implementation and the effectiveness of this programme. However, Shamsazila, Muhd. Faizal \& Ghazali (2017) identified that the teachers in Kuala Lumpur and Wilayah Persekutuan had high readiness and implementation of the i-Think programme. In contrast, the practice among school teachers particularly English teaching in rural secondary school was yet to be explored.

Hence, this paper aimed to investigate the attitude and the practice level of English language teachers in rural schools on the use of $i$-Think maps subsequent to the training and exposure to the programme.

The research objectives of this paper were to discover:

i) the attitude of ESL teachers in rural secondary schools towards the implementation of I-THINK in classroom

ii) the practice level on the use of i-Think among the English language teachers in rural secondary schools

The research questions of this paper were:

i) What does the attitude of i-Think use among the ESL teachers in rural secondary schools?

ii) What is the practice level on the use of i-Think among the English language teachers in rural secondary schools? 


\section{The Rural Secondary School Teachers' Use Of I-Think In Their Classroom}

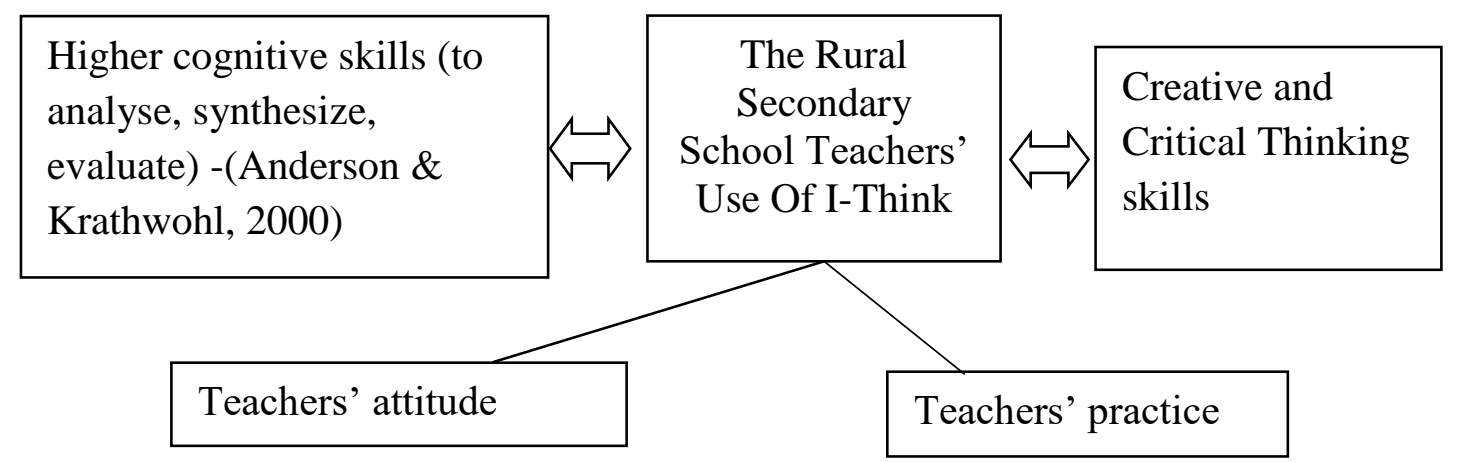

\section{Figure 1: The Conceptual Framework Of The Use Of I-THINK Among English Language Teachers}

The study was conducted in secondary schools in Merlimau area, which is under the category of rural area. The unit analysis was the English language teachers in all secondary schools in Merlimau zone. There are 6 schools with 49 teachers teaching English.

The findings of the paper were expected to provide the local district education and state education department officers the raw facts and data for them to take any further actions if necessary.

The paper had four parts. First, it reviewed the literature relevant to the use of i-Think map. Secondly, the research methodology was illustrated, and data analysis techniques were discussed. Later, the findings were discussed and summarized. At the end of this paper, there was the discussion of implications and direction of further research.

\section{Literature Review}

The students in rural areas are weak in English. According to Rany S. et. al 2013) one of the factors that causes limited English proficiency is "students who came from rural areas are less exposed in using the English language". Family background also plays a role in influencing the use of English in their daily communication. This will hinder the fulfilling of the New National Education Blueprint., Shift 2 particularly.

The Programme for International Student Assessment (PISA) assesses students worldwide on their performance in Mathematics, Science and reading. The result showed that Malaysia was the $52^{\text {nd }}$ in 2015 out of the 74 countries taking part. This did not bode well for Malaysia.

The responsibility to ensure the fulfilling of the Malaysia Education Blueprint relies heavily on teachers. Therefore, the Ministry of Education has planned many strategies to upgrade the achievement of Malaysian students for the benefit of the country and also the students themselves. Rosnidar (2012) opined that pedagogical knowledge regarding the teaching methods, the use of various available sources and teaching aid and distinct teaching strategies should be the epicentre of education field.

Hence, i-Think had been perceived to be a tool set to support effective instructional practice and improve students' performance. The visual maps which are based on thinking processes minimize confusion by poorly organized brainstorming webs or static graphic organizers. The tool provides a consistent and a compatible way for teachers to present information and for students to learn and retain it as i-Think combines the cognitive thought processes of learning 
with the visual representation of information found in graphic organizers (David Hyerle, 2011)

Since the launching of i-Think programme on $13^{\text {th }}$ March 2012, the training of teachers throughout the country to use the i-Think map has been ongoing to ensure all teachers are fully equipped with the i-Think knowledge. Knowledge is information and expertise, or skills gained through experience or training and education (Rohani, 2011). Educators must master the classroom instructions in the implementation of I-THINK to guide students to utilize their higher order thinking skills. In Malaysian context, urging students to use their higher order thinking skills frequently in their thinking process in teaching and learning sessions is still relatively new

In the context of English language teaching particularly, critical thinking enhances students' language and presentation skills. As critical thinking promotes creativity, students will come up with creative solutions to problems by thinking outside of the box and have better judgement and evaluation abilities. Critical thinkers are more independent, autonomous and self-directed learners. The i-Think implementation is the step taken to develop and inculcate critical and creative thinking among students (Islam, R. 2015)

Zulnaidi and Zakaria (2010) identified that using thinking maps might enhance students' conceptual aptitude. Nik Nur Farihah (2014) found that the positive attitude and perception level of students towards the use of i-Think we're very high. This is a good sign of the effectiveness of the use of i-Think throughout the schools in the country. In Melaka, teachers were knowledgeable in the use of i-Think maps, but the implementation in classroom was at average level (Melati Ahmad, 2008).

Mazlan et al (2017) discovered that History teachers' practice of I-THINK in classroom was still at average level. However, the practice among school teachers particularly English teaching in rural secondary school was yet to be explored.

\section{Methodology}

\section{Research Design}

The study employed a survey-based data collection on rural secondary school teachers' attitude and current level of practices.

\section{Sample}

The study was conducted in secondary schools in Merlimau zone. There are 6 schools altogether boasting 49 English language teachers. The Merlimau zone is under the category of rural area. All English language teachers in Merlimau zone secondary schools were included as the population in the study, hence, it is a total population study.

The sampling was a purposive sampling as the participants were selected based on the characteristics of the population.

\section{Research Instrument}

The study was a descriptive quantitative one. To discover the attitude and the level of practice on the use of i-Think maps among English teachers in rural secondary schools area specifically Merlimau zone, the researcher used Likert-scale questionnaire which were adapted from Hazlin (2016) and Zuraida (2008). 
Out of the 49 survey forms which were distributed, only 40 were returned. However, only 33 were analyzed as the remaining 7 failed to answer the trap question. The respondents consisted of 10 male and 23 female teachers. They had between 2 years to 33 years of teaching experience. The age range is between 25 to 56 years old. 24 of them had gone through the courses carried out by the Ministry of Education, District Education Office or their schools on the use of i-Think and 9 had not with different reasons.

\section{Data Collection}

The data for the study was collected after 3 weeks of the questionnaire distribution. No incentives were provided to complete the questionnaires.

\section{Measures}

Likert-scale questionnaire adapted from Zuraida (2008) and Hazlin (2016) were employed. The 49 respondents from the 6 secondary schools in Merlimau zone were asked on their attitude towards the implementation of I-THINK and their level of practice on the use of i-Think maps.

\section{Data Analysis}

The data gathered were analyzed using Statistical Packages for Social Science (SPSS) version 22.0. The descriptive statistics was used to discover frequency distribution, percentage and mean.

\section{Validity and Reliability}

The instruments were appropriate to be utilized to collect data because they were relevant to the study's objectives and research questions. The validity of the collected data was ensured as an expert and 2 senior teachers were consulted before the instruments were employed in the study. Cronbach's alpha was also used to measure the reliability of the questionnaire.

\section{Findings And Discussion}

\section{Finding}

The demographic characteristics of the 33 respondents were summarized in Table 1.

Table 1: The Demographic Characteristics Of The 33 Respondents

\begin{tabular}{lcc}
\hline \multicolumn{1}{l}{ Frequency } & $\mathbf{( \% )}$ \\
\hline Male & 10 & 30.3 \\
Female & 23 & 69.7 \\
Age & & \\
20-30-year-old & 12 & 36.4 \\
31-40 years old & 6 & 18.2 \\
41- 50 years old & 9 & 27.3 \\
$>$ 50 years old & 6 & 18.2 \\
Teaching Years & & \\
$<5$ years & 9 & 27.3 \\
6-10 years & 7 & 21.2 \\
11-15 years & 3 & 9.1 \\
16-20 years & 4 & 12.1 \\
\hline
\end{tabular}




\begin{tabular}{lcc}
\hline $21-25$ years & 4 & 12.1 \\
26-30 years & 5 & 15.2 \\
$>31$ years & 1 & 3 \\
Attended Course/s & & \\
Yes & 24 & 72.7 \\
No & 9 & 27.3 \\
\hline
\end{tabular}

\section{Descriptive Analysis}

In this research, descriptive analysis in the form of frequency, percentage and mean values was executed for two variables namely attitude and level of practice.

Research Question 1: What is the attitude of i-Think use among the ESL teachers in rural secondary schools?

Table 2: Attitude Towards The Implementation Of I-THINK In Classroom Instruction

\begin{tabular}{|c|c|c|c|c|c|}
\hline Features & Responses & $\mathbf{N}=33$ & $\%$ & Mean & Level \\
\hline Liked to utilize & $\begin{array}{l}\text { Disagree } \\
\text { Unsure } \\
\text { Agree }\end{array}$ & $\begin{array}{l}1 \\
7 \\
25\end{array}$ & $\begin{array}{l}3 \\
21.2 \\
75.7\end{array}$ & 3.85 & High \\
\hline Always employed & $\begin{array}{l}\text { Disagree } \\
\text { Unsure } \\
\text { Agree }\end{array}$ & $\begin{array}{l}- \\
12 \\
21\end{array}$ & $\begin{array}{l}- \\
36.4 \\
63.6\end{array}$ & 3.64 & High \\
\hline $\begin{array}{l}\text { Felt it was easy, } \\
\text { convenient, fun, } \\
\text { effective }\end{array}$ & $\begin{array}{l}\text { Disagree } \\
\text { Unsure } \\
\text { Agree }\end{array}$ & $\begin{array}{l}- \\
5 \\
28\end{array}$ & $\begin{array}{l}- \\
15.2 \\
84.4\end{array}$ & 3.85 & High \\
\hline $\begin{array}{l}\text { Always upgraded } \\
\text { their knowledge }\end{array}$ & $\begin{array}{l}\text { Disagree } \\
\text { Unsure } \\
\text { Agree }\end{array}$ & $\begin{array}{l}2 \\
12 \\
19\end{array}$ & $\begin{array}{l}6.1 \\
36.4 \\
57.6\end{array}$ & 3.52 & High \\
\hline $\begin{array}{l}\text { It changed their } \\
\text { teaching patterns }\end{array}$ & $\begin{array}{l}\text { Disagree } \\
\text { Unsure } \\
\text { Agree }\end{array}$ & $\begin{array}{l}3 \\
16 \\
14\end{array}$ & $\begin{array}{l}9.1 \\
48.5 \\
42.4\end{array}$ & 3.33 & Average \\
\hline $\begin{array}{l}\text { Liked to } \\
\text { collaborate with } \\
\text { colleagues }\end{array}$ & $\begin{array}{l}\text { Disagree } \\
\text { Unsure } \\
\text { Agree }\end{array}$ & $\begin{array}{l}5 \\
13 \\
16\end{array}$ & $\begin{array}{l}15.2 \\
39.4 \\
45.5\end{array}$ & 3.3 & Average \\
\hline $\begin{array}{l}\text { Liked to go for } \\
\text { other courses }\end{array}$ & $\begin{array}{l}\text { Disagree } \\
\text { Unsure } \\
\text { Agree }\end{array}$ & $\begin{array}{l}3 \\
11 \\
19\end{array}$ & $\begin{array}{l}9.1 \\
33.3 \\
57.5\end{array}$ & 3.52 & High \\
\hline
\end{tabular}

The descriptive analysis shows that the average mean score of the teachers' attitude towards the I-THINK implementation was high. According to the table, Item 1 had the majority of the respondents agreeing (mean $=3.85$ ). Items exploring the effectiveness of I-THINK also garnered the mean score of 3.85. The emerging theme is that not only the respondents like 
incorporating I-THINK in class, the respondents concurred that I-THINK helped in classroom instruction and was effective to assist students to understand the topics taught better. This fulfills the aspiration planned by the Ministry of Education to equip teachers with assessment and teaching of $21^{\text {st }}$ century skills.

In contrast, the items exploring whether the teachers' teaching pattern had changed and whether they liked to work collaboratively obtained average mean scores of 3.33 and 3.30 respectively. Hence, it was found that many of the teachers did not think that I-THINK had changed their teaching patterns. This was attributed to the reason that even though I-THINK was first officially launched in the year 2012 in Malaysia, the use of thinking maps as a teaching tool had started in 1970, when Innovative Science Incorporated (ISI) founded by Charles Adam promoted it. David Hyerle himself wrote 'Expand your Thinking' in 1988, the book which incorporated the first thinking maps masterminded by him. Thus, some experienced teachers had started using thinking maps since before the introduction of I-THINK in 2012.

Another reason why a number of teachers did not think I-THINK had changed their teaching patterns was because they would not employ I-THINK in classrooms with weak students. It would be extremely time-consuming as low proficiency students would need constant guidance to perform the tasks and most of the time these students would not even co-operate.

However, this has to change. The failure rate in English subject is high in rural areas (Wahab et. al. 2004). If teachers do not change their attitude and reject I-THINK employment when teaching low proficiency students, these learners will have minor opportunity to join the $21^{\text {st }}$ century workforce and compete with their urban counterpart when they complete school.

The teachers also inclined to work on their own. However, ESL teachers should join forces and cooperate to upgrade their skills and knowledge. They must have discussions too to generate ideas on new approaches to utilize and practice in their teaching profession for the benefits of the students. By interacting with the the colleagues, the teachers can develop and maximize their cognitive skill themselves to be progressive and constructive educators. Imperative to $21^{\text {st }}$ century learning, educators must contrive to vary their teaching methods and constantly find ways to horn the learners' $21^{\text {st }}$ century skills (Sivalingam \& Yunus, MM (2017). They cannot wait, they must act.

Research Question 2: What is the practice level on the use of i-Think among the English language teachers in rural secondary schools?

Table 3: Practice Of I-THINK In Classroom Instruction

\begin{tabular}{llllll}
\hline \multicolumn{1}{c}{ Features } & \multicolumn{1}{c}{ Responses } & $\begin{array}{c}\mathbf{N =} \\
\mathbf{3 3}\end{array}$ & $\mathbf{\%}$ & Mean & Level \\
\hline $\begin{array}{l}\text { Employed circle map in } \\
\text { brainstorming activity }\end{array}$ & Infrequent & 5 & 15.1 & 3.27 & Average \\
& Relatively Frequent & 15 & 45.5 & & \\
& Frequent & 13 & 39.4 & & High \\
$\begin{array}{l}\text { Employed bubble maps } \\
\text { to identify adjectives/ } \\
\text { characteristic }\end{array}$ & Infrequent & 3 & 9.1 & 3.52 & \\
\hline
\end{tabular}




\begin{tabular}{|c|c|c|c|c|c|}
\hline & Frequent & 18 & 54.6 & & \\
\hline \multirow{3}{*}{$\begin{array}{l}\text { Employed double } \\
\text { bubble map to compare } \\
\text { and contrast }\end{array}$} & Infrequent & 6 & 18.2 & \multirow[t]{3}{*}{3.36} & \multirow[t]{3}{*}{ Average } \\
\hline & & 10 & 30.3 & & \\
\hline & Relatively Frequent & 17 & 51.5 & & \\
\hline \multirow{4}{*}{$\begin{array}{l}\text { Employed tree map to } \\
\text { classify/ identify ideas }\end{array}$} & Frequent & & & \multirow{4}{*}{3.39} & \multirow{4}{*}{ Average } \\
\hline & Infrequent & 6 & 18.2 & & \\
\hline & Relatively Frequent & 10 & 30.3 & & \\
\hline & Frequent & 17 & 51.6 & & \\
\hline \multirow{3}{*}{$\begin{array}{l}\text { Employed brace map to } \\
\text { analyse physical object }\end{array}$} & Infrequent & 14 & 42.4 & \multirow[t]{3}{*}{2.75} & \multirow[t]{3}{*}{ Average } \\
\hline & Relatively Frequent & 10 & 30.3 & & \\
\hline & Frequent & 9 & 27.3 & & \\
\hline \multirow{3}{*}{$\begin{array}{l}\text { Employed flow map to } \\
\text { write synopsis }\end{array}$} & Infrequent & 7 & 21.3 & \multirow[t]{3}{*}{3.30} & \multirow[t]{3}{*}{ Average } \\
\hline & Relatively Frequent & 8 & 24.2 & & \\
\hline & Frequent & 18 & 54.5 & & \\
\hline \multirow{3}{*}{$\begin{array}{l}\text { Employed multi-flow } \\
\text { map to analyse causal } \\
\text { relationship and } \\
\text { consequences }\end{array}$} & Infrequent & 6 & 18.2 & \multirow[t]{3}{*}{3.12} & \multirow[t]{3}{*}{ Average } \\
\hline & Relatively Frequent & 15 & 45.5 & & \\
\hline & Frequent & 12 & 36.4 & & \\
\hline \multirow{3}{*}{$\begin{array}{l}\text { Employed the bridge } \\
\text { map to apply analogy } \\
\text { process }\end{array}$} & Infrequent & 11 & 33.3 & \multirow[t]{3}{*}{2.85} & \multirow[t]{3}{*}{ Average } \\
\hline & Relatively Frequent & 13 & 39.4 & & \\
\hline & Frequent & 9 & 27.3 & & \\
\hline
\end{tabular}

The descriptive analysis shows that the average mean score of the teachers' level of practice on the I-THINK utilization was average. This reveals that despite the positive attitude shown by the teachers towards the I-THINK programme, their practice level was not as encouraging.

The rest of the items garnered average mean scores except for Item 2. The percentage and mean score were quite significant to show that the majority of the teachers did practice the use of bubble-map in their teaching and learning session. However, this positive vibe could not be seen in other items.

It is worth noting that there were 2 items which accumulated the lowest average mean scores which were Items 5 and 8 . This reflects that teachers had the least competency when using brace map to teach students analyzing a physical object and when using bridge map to teach students applying analogy process by employing relationship factors. This can be attributed to the insufficient exposure in the form of attending courses and teachers' confidence deficiency to employ the tools in classrooms. 
Overall, based on the findings from the questionnaire, the level of practice on I-THINK among rural secondary school ESL teachers was average. The teachers were selective and not using the I-THINK maps extensively. The teachers lacked competency in using certain thinking maps as some of them had not attended any I-THINK course. Measures must be taken to solve the identified issues that this research has discovered.

\section{Discussion}

Through the attitude survey, the study demonstrates that the respondents, had positively responded to the I-THINK programme The majority of the teachers made efforts to upgrade their skills to master the implementation as it was found to be fun and effective to assist teachers to impart knowledge to students.

However, the finding for the practice level of the teachers on the I-THINK implementation was not as encouraging. Teachers only used certain I-THINK maps to be incorporated into their classroom instructions and most teachers only used the thinking maps either infrequently or relatively frequent. The ESL teachers' attitude was positive towards the I-THINK programme to enhance students' performance; however, they did not show similar enthusiasm in practising it in class.

\section{Conclusion}

The research aimed at exploring the rural secondary school ESL teachers' attitude and practice level on the use of I-THINK as classroom instruction. Even though the findings of this study may be specific to the secondary school teachers in Merlimau zone, their implications are significant to other educators as well. The teachers' positive attitudes in the current study have a special significance given the limitation of exposure in the form of courses that the teachers' receive. It is essential for the policy-makers to sustain and enhance the teachers' positive attitude as it is a prerequisite to ensure teachers' full cooperation to fully utilize I-THINK in classrooms.

Despite the buoyant attitude toward the implementation of I-THINK, the rural secondary school teachers showed lukewarm performance at practicing the thinking maps. The policy-makers need to pay attention to this shortcoming. The findings require the school administration's, the District Education Office's, the State Education Department's and the Ministry of Education's thought, planning and support. Without all those three, the teachers in rural areas are unlikely to vigorously use the I-THINK approach in their practices.

On the other hand, the ESL teachers themselves should start the initiatives to obtain additional mentoring and support from school and their colleagues to boost their practice level in I-THINK implementation. They should expose themselves to the off-line I-THINK course (KiLT) designed by the Ministry of Education to be more conversant with the I-THINK for the good of the students. Teachers' role is important to influence students to use a learning approach. Cope \& Ward (2002) opined that if teachers are interested and directed towards students and changing their conceptions, students are inclined to use the method prescribed by their teachers. Hence, teachers need to be intrinsically motivated to apply the I-THINK approaches in class to ensure the generation of students with better outcomes. I-THINK as part of the $21^{\text {st }}$ century teaching method must be incorporated in the classroom instruction in rural secondary school specially to keep in pace with the students in urban area. Since Shamsazila, Muhd. Faizal \& Ghazali (2017) have identified that the teachers in Kuala Lumpur and Wilayah Persekutuan have high readiness and implementation of the i-Think programme. 
The study had a small sample consisting of respondents from 6 rural secondary schools in Merlimau zone, Melaka. The findings generated from the 33 ESL teachers may not reflect the real scenario in Malaysia regarding the I-THINK implementation in rural secondary schools. Hence, other researchers may want to explore the same issues raised in this study on other respondents throughout Malaysia to get a better picture of corresponding researches.

Future study may perhaps investigate the explanations of why despite the positive attitudes among the ESL teachers in the rural secondary school towards I-THINK programme, their level of practice is not as heartening. The challenges and issues faced by the rural area teachers in the implementation of I-THINK in language classroom can also be explored. Interviews and observations may be included as data collection methods to triangulate the quantitative data.

\section{References}

Anderson, A. \& Krathwohl, D. (2000). A taxonomy for Learning, Teaching and Assessing: A Revision of Bloom's Taxonomy of Educational Objectives. (2 ${ }^{\text {nd }}$ ed.) New York: Allyn \& Bacon

Cope, C. \& Ward, P. (2002). Integrating Learning Technology Into Classrooms: The Importance Of Teachers' Perception. Educational Technology \& Society, 5 (1), 67-74.

Creswell, J. W. (2005). Educational Research: Planning, Conducting, And Evaluating Quantitive And Qualitative Research. New Jersey: Upper Saddle River

Hyerle, D. (2009) Thinking Maps: A Synthesis Language Of Visual Tools. Visual Tools For Transforming Information Into Knowledge (2nd, pp.115-144) Corwin Pres.

Lim, Md. Yunos M. \& Maslawati Mohamad, M. S. (2016, June 29). The Malaysian Education Blueprint 2013 And Its Effects On English Language Teaching In Malaysia [Forum post]. Retrieved from https://www.tesol.id

Malaysia Education Blueprint 2013-2025 Ministry of Education Malaysia - KPM https://www.moe.gov.my

Mazlan Hussin, Mohd. Mahzan Awang \& Anuar Ahmad (2017) Teacher readiness in teaching and learning process of History using I-think mind-maps. Yupa : Historical Studies Journal 1 (2): 183-198

Muhamad Sidek Said, Mohamad Ab. Kadir, \& Mohamad Sabri Awang Hitam (2013). Penilaian Pelaksanaan Program i-Think: Satu Pengenalan. Ejurnal.lpgmksm.Edu.My, 1-8. Retrieved from http://www.ejurnal.ipgmksm.edu.my/pdf/kajian1.pdf

Nik Harmi, Nik Nur Farihah Mahamod, \& Zamri (2015) Keberkesanan Kaedah Peta Pemikiran (I-Think) Terhadap Pencapaian, Sikap Dan Kesediaan Murid Tingkatan Empat, (May), 13955.

Official Portal Of Malaysian Education Ministry 2017. KPM. 100-15/3/9 JLD. 6 (92) dated 27 October 2017: The Execution of Off-line I-THINK course (KILT) in Malaysian schools.

Partnership for $21^{\text {st }}$ Century Learning. (2009). Framework for $21^{\text {st }}$ Learning http://www.p21.org/our-work/p21-framework

PISA 2015 Results in Focus - OECD.org https://www.oecd.org>pisa>pisa-2015

Rany, S. \& Mohamad Z. A., Jafre (2013) Factors Causing Students' Low English Language Learning; a Case Study In The National University Of Laos: English in Education doi 10.5296/ijele. v1i1.3100

Rashidah Radzi Rasalingam (2018) Use of CLT in teaching English courses at Malaysian

Polytechnique: Masters UKM Bangi. 
Rohani Aziz (2011) Pengetahuan, Sikap dan Kemahiran ICT di Kalangan Guru Matematik di Sekolah Menengah di Negeri Pahang. Tesis Sarjana, Fakulti Pendidikan, Universiti Kebangsaan Malaysia

Rosnidar Mansor (2011) Pengetahuan Pedagogikal Isi Kandungan (PPIK) Guru dan Kefahaman Konseptual Pelajar Dalam Topik Respirasi. Tesis Doktor Falsafah, Fakulti Pendidikan, Universiti Kebangsaan Malaysia

S. M. Rayhanul Islam (2016) What Are The Importance And Benefits of 'Critical Thinking'? Retrieved from https://www.linkedin.com

Sivalingam, P. \& Yunus, M. M. (2017) Nurturing $21^{\text {st }}$ century skills through service learning: from isolation to connection: People: International Journal of Social Sciences. Special Issue Volume 3 Issue 1, pp. 346-356

Thinking Maps Inc. www.thinkingmaps.com

Thirusanku, J., Melor, M. Y. (2012). The Many Faces of Malaysian English. International Scholarly Research Network.doi: 10.5402/2012/138982

Wahidin (2004) Peta Konsep, Peta Vee dan Kemahiran Berfikir dalam Pengajaran Kimia. Tesis Doktor Falsafah. Bangi: Fakulti Pendidikan, UKM

W. P., \& Stoller, F. L. (2013). Teaching And Researching: Reading. Routledge.

Yenni Muliani (2012) Hubungan Antara Pengetahuan dan Kesediaan Pelaksanaan Pengajaran Bahasa Arab Kurikulum Tingkat Sarjana Pendidikan di Acheh. Tesis Fakulti Pendidikan, Universiti Kebangsaan Malaysia

Yip, W. M. \& Kwan, C. M., (2006) Online Vocabulary Games As a Tool For Teaching And Learning English Vocabulary: Educational Media International Vol. 43, no 3 pp. 233-249 Grabe,

Zulnaidi, H. \& Zakaria, E. (2010) The Effect Of Information Mapping Strategy On Mathematics Conceptual Knowledge Of Junior High School Students. US- China Education Review, 7(1), 26-31

Zuraidah Saat (2008) Kemahiran, Sikap dan Kekerapan Penggunaan Komputer Dalam Kalangan Guru Bahasa Melayu. Projek Sarjana Pendidikan, Bangi: Fakulti Pendidikan UKM. 